DOI No: http://dx.doi.org/10.29228/Joh.50688 Authenticity process is conducted by

Makale Türü: Araştırma makalesi

Geliş Tarihi: 02-04-2021

Kabul Tarihi: 21-06-2021

On-line Yayın: 31-06-2021
Article Type: Research article Submitted: 02-04-2021 Accepted: 21-06-2021

Published Online: 31-06-2021

Atff Bilgisi / Reference Information

Öztürk, S. \& Güleç, E. (2021). Makale Başlığı sadece ilk harfler büyük, Times New Roman 10 punto. Journal of History School, 53, 2906-2921.

\title{
ABSTRACTION THROUGH EDITING IN EXPERIMENTAL CINEMA: VISIONS IN MEDITATION SHORT MOVIE TETRALOGY ${ }^{1}$ Serkan ÖZTÜRK ${ }^{2} \&$ Ecem GÜLEÇ 3
}

\begin{abstract}
Cinema is one of the mediums that artists can reflect their perspectives, intuitions, feelings, and emotions, and it is highly prominent from the time of its conception. Since from its conception, cinema, has renovated itself through auteur directors and their styles and movements. And one of cinema's greatest building block have always been editing which gave its finalized form. The artist can reflect his/her aesthetic language and can direct his/her narrative through the usage of editing. This reflection and direction make the editing one of the more fundamental dynamics of the art of filmmaking. Especially Russian Avant-garde filmmakers developed various editing techniques to make the narrative of the movie to reflect subjective and social realities in a way that it is closer to the "truth" while also placing it in the center of the cinematic narrative. In time, editing become free from its shackles and opened itself to experimental cinema. The editing techniques that were invented to relay the truth better became one of the tools that let artists detach themselves from reality to better articulate their points. This research aims to investigate the role of editing that made detachment of the artist in their own cinematic narrative from their realities. This research will examine Stan Barkhage's Visions in Meditation (1989-1990) short movie tetralogy through the exemplifications of Eisenstein's avant-garde editing styles that underlies editing in cinema and Vertov's

\footnotetext{
${ }^{1}$ Makale yazımı yazar etki oranı: 1.yazar: $\% 50,2$. yazar: $\% 50$.

${ }^{2}$ Assoc. Prof., Yalova University, Faculty of Humanities and Social Sciences, Department of New Media and Communication, serkan.ozturk@yalova.edu.tr, Orcid: 0000-0001-8882-3607

3 R.A., Yalova University, Faculty of Art and Design, Department of Graphic Design, mecemgulec@gmail.com, Orcid: 0000-0003-1922-5579
} 
Abstraction Through Editing in Experimental Cinema: Visions in Meditation...

avant-garde brotherhood while utilizing literature reviews and content analyses methodologies. From the findings that are gathered within the research, how a cinematic narrative become abstracted by editing and how editing creates an aesthetic language will be discussed.

Keywords: Stan Brakhage, Visions in Meditation, Avant-Garde, Experimental Cinema, Editing

\section{Deneysel Sinemada Kurgunun Soyut Anlatısı: Visions in Meditation Kisa Film Dörtlemesi}

\section{$\ddot{\mathbf{O z}}$}

Sinema, sanatçının perspektifini, algısını, duygusunu, hislerini yansıtabileceği araçlardan biridir ve icat edildiği tarihten beri varlığını sürdüren bir disiplindir. Var oluşundan beri sürekli kendini yenilemiş ve alanın autuer yönetmenleri tarafından akımlar ve tarzlarla güncelliğini korumuştur. Sinemayı var eden en büyük unsurlardan biri de onu kesip biçerek doğuran kurgudur. Sanatçı, estetik dilini kurguyla dışa vurabilir ve anlatımını dilediği gibi yönlendirebilir. Bu da kurguyu, film yapımının en güçlü dinamiklerinden biri haline getirir. Özellikle Rus Avangart sinemacılar, kurguyu sinemasal anlatının temeline yerleştirirken onu toplumsal ve öznel gerçeklikleri yansıtmak ve "gerçeğe" daha da yaklaştırmak için çeşitli teknikler geliştirmişlerdir. Zamanla kurgu, bağımsızlığını ilan ederek deneysel sinemaya kapısını açmıştır. Gerçekliği daha iyi aktarabilmek için kullanılan kurgu teknikleri, zamanla sanatçının gerçekliği soyutlayarak, kendini ifade etme biçimine dönüşmüştür. Ele alınan araştırma, sanatçının sinemasal anlatısında, kurgunun gerçekliği nasıl soyutlayarak var olduğunu araştırmayı amaçlamaktadır. Yöntem olarak literatür taraması ve içerik analizinin benimsendiği araștırmada, sinemada kurgu kavramının altını çizen Eisenstein'ın avangart kurgu biçimlerinden yola çıkarak, onun gibi kurguyu ustaca kullanan Vertov'un avangart yoldaşlığı ile amaçlı örneklem metodu kullanılarak seçilen avangart sanatçı Stan Brakhage'in Visions in Meditation (1989-1990) kısa film dörtlemesi incelenecektir. Ele alınan yaklaşımlar ışı̆̆ında, araştırmanın sonucunda sinemasal anlatının kurgu ile nasıl soyutlandığ ve kurgunun nasıl bir estetik dil oluşturduğu tartışılacaktır.

Anahtar Kelimeler: Stan Brakhage, Visions in Meditation, Avangart, Deneysel Sinema, Kurgu

\section{INTRODUCTION}

Cinema has been a medium that transmits the moments, experiences, feelings and thoughts since its existence. While at the time of its invention it was 


\section{Serkan ÖZTÜRK \& Ecem GÜLEÇ}

seen as a technical invention capable of reflecting images taken from daily life, over time, art was also incorporated into its technical aspect. One of the elements that turns cinema into art is editing. Editing, which is capable of directing the course of cinematic narrative, was developed through different methods, especially by Russian avant-garde filmmakers. While conveying the reality in their films, Russian avant-garde filmmakers used the influence of editing to a great extent in order to get closer to the reality itself. Editing is an important aspect of the artist's aesthetic language as well as a technical tool. While editing can be used to utilize the reality as it is, it can also be used to isolate the films from reality. Especially in experimental cinema, editing has become an art tool that can create an abstract perception in the cinematic narrative. Using this approach, this research aims to examine the usage of editing in experimental cinema as an artistic tool as well as a tool that can isolate the film from reality. Based on editing-centred experimental cinema, the research limits itself to the avant-garde movie universe while maintaining its focus on Stan Brakhage's Visions in Meditation short movie tetralogy and its editing practices. Stan Brakhage's importance among the avant-garde filmmakers and his contributions to the conceptual process and visual aesthetics of the cinema in general are the main reasons behind the selection of the sample.

A literature review indicates that while foreign studies examining the cinematic narrative styles of Stan Brakhage are present, there is only one academic study related to Stan Brakhage in Turkey, and it addresses his experimental cinema from the angle of political cinema. While the current studies acted as a source for this research, unlike them, this will focus on editing and experimental cinema, while examining the possibilities held by editing and the kind of abstract narrative it creates by the cinematic approach of Stan Brakhage and his Visions in Meditation short film tetralogy produced between 1989 and 1990 .

\section{Editing and Eisenstein}

Editing is basically a film technique that connects the shots. After cutting the unwanted parts of the raw shots, the intended parts are combined by editing. The director establishes a connection between the shots in accordance with the purpose of the film and the coordination of these shots is ensured by editing. While the shots are combined by editing, the correlation between them is established and supervised in four fundamental areas: The first correlation is "graphic relations between shot A and shot B"; On behalf of the interaction of the "purely pictorial" characteristics of shot A and shot B, these two shots are 
constructed by using the similarities or differences of graphical elements between those two shots. The second correlation is "rhythmic relations between shot A and shot B." Each shot has a specific duration and the correlation is made between the durations of appearance of these shots on the screen. The rhythmic capacity of editing is regulated by the filmmaker through adjustment of the duration of shots in relation to one another. The third correlation is "spatial relations between shot A and shot B." In order to create the film space, the editing enables the director to associate "any two points in space" by comparing, contrasting or developing them. Lastly, the fourth correlation is "temporal relations between shot A and shot B." The time of the action portrayed in the film can be manipulated by editing the story time as per the plotline (Bordwell and Thompson, 1997, p.273-283).

In an attempt to strengthen the narration, the relationships between the shots are edited as per director's preference. The purpose of the editing that strengthens cinematic narration, as film theorist André Bazin (1967/2005, p.25) stated, is "the creation of a sense or meaning", which can be achieved by the "juxtaposition" of the images. In the editing process, different techniques can be used to juxtapose the images. For instance if we take shots A and B, those two shots can be joined together via using fade-out and fade-in methods by making the image disappear into darkness towards the end of shot $\mathrm{A}$ and then making it reappear from the darkness in shot B.The combination of $\mathrm{A}$ and $\mathrm{B}$ shots by blending the two is conducted through the dissolve technique. In this method, the image of shot B gradually superimposes and appears on the image of shot A, and phase by phase, shot A disappears. Splicing the shots A and B without using fadeout, fade-in or dissolve is done by cut method (Bordwell and Thompson, 1997, p.270-271).

One of the most prominent figures in cinema associated with editing is the Russian avant-garde filmmaker Sergei Eisenstein who had a great influence on the theories of cinema and editing. According to Wollen (1972, p.9), "Eisenstein was the first, and probably still the most important, major theorist of the cinema". Putting the editing in the center of cinema, Eisenstein emphasize the importance of editing by saying "the essence of cinema should not be sought in the images but in the relations between the images." The influence of Eisenstein's theatre background, especially Meyerhold Theatre, planted the seeds of his editing theories (cited Özön, 2014, p.xli-cxvi).

In his book Film Form, Eisenstein categorized the editing methods into five types - metric montage, rhythmic montage, tonal montage, overtonal montage and intellectual montage. In the metric montage method, in which the 


\section{Serkan ÖZTÜRK \& Ecem GÜLEÇ}

key criterion is the "absolute length" of the shots, the lengths of the images are formulated to correspond to the repetition of a musical measure pattern while the shots are combined. Unlike the metric montage, in which the move is determined according to the length of the shots; in the rhythmic montage, the motion in the content of the frames is taken as a basis to designate the length of the shots. As an example to rhythmic montage, Eisenstein mentions the Odessa steps sequence in Battleship Potempkin movie. The move of editing within the sequence is maintained by the moves within the frame (Eisenstein, 1949/1977, p.72-75) The audience's eye is guided along the lines of moving objects or stationary objects within images (Özön, 2014, p.cxxvii). Eisenstein states that the term tonal montage, which refers to "a stage beyond rhythmic montage", was used for the first time. He expresses that the move of the rhythmic montage within the frame spreads over a wider area in tonal montage and that the "graphic tonality" of the optical light vibrations in the shots gains prominence in terms of editing. Thus, the editing process is shaped through the "emotional sound" of the dominant element of the shots. Overtonal montage is, by Eisenstein's words, "is distinguishable from tonal montage by the collective calculation of all the piece's appeals". In other words, by including the three types of editing mentioned, "a physiological perception" is created with the overtonal montage, in which the measure of the length, the motion and the tonality of the shot are evaluated together. Therefore, the physical sensations created by the metric, rhythmic and tonal montage are taken to the next level, enabling the flow of the sequence to create a more intense and impressive perception (Eisenstein, 1949/1977, p.75$81)$.

Last but not least comes the intellectual montage which Eisenstein describes as "a still higher category". Intellectual montage based on "sounds and overtones of an intellectual sort" is a "conflict-juxtaposition of accompanying intellectual affects" (Eisenstein, 1949/1977, p.81-82). Eisenstein, who sees cinema as "the only concrete art that is both dynamic and awakes thought process" refers to the intellectual montage in a conference as follows; "Filming abstract concepts with the help of images, embodying these abstract concepts to some extent. And to do this by finding a way to elicit predetermined, calculated emotional reactions directly from the images or the arrangement of the images, not a concept with the support of any story or anecdote... It has to realize a series of pre-arranged images in such a way that it creates an emotional move that progresses to a series of thoughts..." (Özön, 2014, p. cxxxii). Eisenstein aimed to bring the abstract concepts to the screen through intellectual cinema theory, hence editing for him was a way of utilizing "the emotive and cognitive powers" of the audience by evoking and expanding them. The filmmaker introduces a path 
Abstraction Through Editing in Experimental Cinema: Visions in Meditation...

drawn by editing of images to the audience and the audience follows this route intellectually (Carrol, 2003, p.138).

\section{Soviet Montage in Experimental Cinema: Kino-Eye}

In contrast to the understanding of mainstream cinema or conventional cinema, experimental cinema involves films that are produced independently from a studio system and with the aesthetic initiatives taken by the directors themselves. These types of film works that exist outside of the common formal structure are often called experimental or avant-garde (Bordwell and Thompson, 1979/2011, s.366). Avant-garde, a militarist term of French origin, is defined as the vanguard of an army advancing before others. The first artistic reference to the term avant-garde came into being in the 19th century when the socialist philosopher Henri de Saint-Simon mentioned it as "We artists will serve you as an avant-garde" (https://www.tate.org.uk/art/art-terms/a/avant-garde Accessed: 28.02.2021). Correspondingly, its presentation within the framework of art can be identified as the pioneer and innovator of the contemporary art it belongs to. Experimental cinema affirms its characterization as avant-garde; since it experiments, discovers, and promotes new forms and subjects in cinema with the intention of existing independently beyond the predominant understanding of the cinema of its era. The film theorist Siegfried Kracauer (1960, p.177) states that the experimental cinema is rooted in the "European avant-garde movement of the '20's and that the influence of this Paris-based avant-garde movement was spread around the world through the expressionist films of the Germans, and "the ingenious montage methods of the Russians." According to Eisenstein; Dziga Vertov, who draws attention among the Russian filmmakers with his use of editing technique and had a great influence on Eisenstein, is the inventor of "musical rhythm in the cinema" (Wollen, 1972, p.41).

After watching Dziga Vertov's Man with a Movie Camera (1929), Kracauer praises the film and defines Vertov's editing as follows: "Vertov uses montage to extract a meaning from the connections between the fragments of reality" (cited Holl, 2017, p.260). Defining the editing on the basis of reality, Vertov's aim is "to show the truth on the screen". Based on the Kino-Eye theory, Kino-Eye will show "which the eye does not see" (Vertov, 1984, p.41-42) because the Kino-Eye, in Vertov's description, "couples together any point in the universe whatsoever to another in any temporal order whatsoever" (cited Deleuze, 1983/1986, p.80). In company with Vertov's editing in which "making the invisible visible" emerging within the art universe of constructivism, the spatial relations between the shots came into prominence. The Kino-eye, as Bazin 


\section{Serkan ÖZTÜRK \& Ecem GÜLEÇ}

(1967/2005, p.54) stated, "employed the crude reality of everyday events in order to give it a place on the dialectic spectrum of montage". Vertov who edits ingeniously has created a significant perception in the cinema by, in Teksoy's (2005, p.136) words, "the combination of fast and slow motion, close and long shots, animation cinema, cinema tricks and shots taken in different places at different times". According to Deleuze (1983/1986, p.70) "Vertov is perhaps the inventor of properly perceptive montage, which is to be developed by the entire field of experimental cinema".

Vertov's editing in which he overlaps different figurations of spatial and temporal "puts perception into matter in a way that it can perceive itself'(Deleuze, 1983/1986, p.81). With reference to Deleuze's explanation of objectivity which is "to see without boundaries or distances", Kino-eye reveals "which the eye does not see" by eliminating "the boundaries or distances" with Vertov's editing techniques (Deleuze, 1983/1986, p.80-82). In the Soviet cinema, editing was built to reflect the reality in the best manner by, as Bazin (1967/2005, p.33) quoted, "increasingly eliminating both plastic expressionism and the symbolic relation between images". From this point of view, for Eisenstein who sees cinema as a whole, the cinema that consists of editing pieces does not only express the wholeness of pieces of images but also the dialogue between the pieces of thoughts. Eisenstein who aspired to create an intellectual process in cinema with editing, in contrary to Vertov's Kino-eye theory, believed in Kino-fist (Baker, 2011, p.96; Wollen, 1972, p.41). While conveying "the life as it is"; Vertov, who wanted "cinema to remain completely objective", designated his shots objectively and reflected them on the screen by correlating between the selected shots. (as cited in Özön, 2014, p.xlvii).

\section{METHOD}

The hypothesis presented through the research are as following;

1. For an artist who accepts the cinema as an art discipline, editing is not only a technical tool, but also an aesthetic concern.

2. Editing as an artistic concern can both create a sense of reality and detach the film from its reality.

In this research conducted by the method of content analysis, the hypotheses above will be built upon the perceptional montage created by Vertov through Kino-eye theory - based on the montage methodology of Eisenstein, who emphasizes the power of editing in cinema theory. They will be examined within the context of avant-garde cinema, which is a commonality shared by Eisenstein 
Abstraction Through Editing in Experimental Cinema: Visions in Meditation...

and Brakhage, and hence the concept of experimental cinema. Within this scope, Brakhage's Visions in Meditation tetralogy will be examined based on the proffered theories of editing, cinema, and the eye perceiving them. The approaches structured as result of the research will be discussed in the conclusion.

\section{FINDINGS AND INTERPRETATION}

American avant-garde filmmaker Stan Brakhage captured most of the moments he experienced by using the camera as a limb. As Göztepe (2010, p.67) depicted, Brakhage creates "a seeing experience by identifying the camera with the eye". According to his wife Marilyn Brakhage (2010), he made 350-400 films during his cinema career. Around half of them are film-poems of less than ten minutes, while the majority of the rest are between ten minutes and an hour, and several of them are longer". While he was shooting his "epic" film Dog Star Man (1961-1964), Brakhage wrote down his thoughts on seeing and vision in his book Metaphors of Vision, which was defined by Marilyn Brakhage (2008) as "his seminal work of theoretical writing". He begins his book with the following words:

"Imagine an eye unruled by man-made laws of perspective, an eye unprejudiced by compositional logic, an eye which does not respond to the name of everything but which must know each object encountered in life through an adventure of perception. How many colors are there in a field of grass to the crawling baby unaware of "Green"? How many rainbows can light create for the untutored eye?" (Brakhage, 1963, s.30).

Stating that the eyes respond to "all visual stimuli," so the vision always on the move ${ }^{4}$, Brakhage endeavored to create a pure vision in his films with his untutored eye theory which he presented as an unprejudiced and untrained eye (Sitney, 2003). As stated by Michelson (2005, p.55), the Cinema of Vision of Stan Brakhage is "dissolving the distance and resolving the disjunction Eisenstein had adopted as the necessary conditions for cinema's cognitive function, he proposes, as the paradigm of contemporary montage style, an alternative to Intellectual Cinema".

Visions in Meditation tetralogy consisting of four series is, according to Sitney (2015 p.171), "a vital engagement with the landscape and a depth of wonder and visual intelligence unsurpassed in all of Brakhage's cinema”. The

\footnotetext{
${ }^{4}$ In the Stan Brakhage (2003) article by Adam Sitney, Sitney derives 7 principles based on the book Metaphors on Vision.
} 


\section{Serkan ÖZTÜRK \& Ecem GÜLEÇ}

first is Visions in Meditation \#1 made by Brakhage in 1989, having inspired by Gertrude Stein's poem Stanzas in Meditation. While describing the film in the catalog entry, his wife Marilyn Brakhage had stated that "the filmmaker has edited a meditative series of images of landscapes and human symbolism 'indicative of that field-of-consciousness within which humanity survives thoughtfully'"(as cited in Sitney, 2008, p.336).

Visions in Meditation \#2: Mesa Verde is defined by Brakhage in the catalog entry as follows: "This meditation takes its visual imperatives from the occasion of Mesa Verde, which I came to see finally as a Time rather than any such solidity as Place" (as cited in Sitney, 2008, p.338). When Brakhage saw the ruins in Mesa Verde ${ }^{5}$, he thought that "there is a terror here" and with the unquietly feeling of the resonation of enigmatic scene of the ruined rocks, he did not believe in an opinion that "the Indians abandoned this solid habitation because of drought, lack-of-water, somesuch". According to him, these reasons are not elucidating "the fact that all memory of The Place, i.e., where it is, was eradicated from tribal memory, leaving only legend of a Time when such a place existed". While expressing his sentiments, Brakhage had to present images in the editing that affirm what the rocks were saying: "The abandonment of Mesa Verde was an eventuality" (https://canyoncinema.com/catalog/film/?i=494, Accessed: 28.02.2021).

Visions in Meditation \#3: Plato's Cave, the third film of the series, which has a soundtrack unlike the others, captures the idea of Plato's cave. Brakhage hoped to bring a spot of "rush light into the darkness" by this film, which he believes is "a vision of mentality as most people must (to the irritation of Plato) have it, safely encaved and metaphorical, for the nervous system to survive". As he suggested in the catalog entry, the representation of Plato's cave in the film is the vortex of the unbearable "the phenomenological world" (https://canyoncinema.com/catalog/film/?i=495, Accessed: 28.02.2021). The allegory of Plato is realized through Brakhage's camera by finding an exit from the cave, and introducing the audience into a screen filled with sunlight. The audience travels by the flow of the camera panning (Sitney, 2008, p.341-344).

The last film of the series is Visions in Meditation \# 4: D. H. Lawrence. Brakhage pursued "to liberate each image within the film to be themselves" in memory of English author, Lawrence. Moreover, he wrote Lawrence's quote in the catalog entry to clarify why the title bears Lawrence's name; "... there must

\footnotetext{
${ }^{5}$ The National Park Mesa Verde, located in the American state of Colorado, has been a settlement for ancestral Puebloans over the 700 years (550 A.D. to 1300 A.D.). See also:

https://www.visitmesaverde.com/discover/park-history/
}

[2914] 
Abstraction Through Editing in Experimental Cinema: Visions in Meditation...

be mutation swifter than iridescence, haste, not rest, come-and-go, not fixity, inconclusiveness, immediacy, the quality of life itself, without denouncement or close" (https://canyoncinema.com/catalog/film/?i=496, Accessed: 28.02.2021).

Visions in Meditation tetralogy, which was constructed by assembling the images taken from different places and different times, follows the same path with intellectual montage which leads to "the visual representation of abstract concepts" in the cinema (Eisenstein, 1949/1977, p.30). However, the point where they diverge at the end of the path is that while intellectual montage concretizes abstract concepts, Visions in Meditation" has a structure where the material is turned into abstract. The incomprehensible images of Brakhage's cinematic narration, according to Michelson (2005, p.54), "devours in its constant renewal both memory and expectation, projecting that "continuous present" which Brakhage had perceived as Gertrude Stein's great and particular lesson for him. The visual narrative of the Visions in Meditation that is not built on completely clear and cognizable narration becomes abstract at one time or another. The relationship between the images that can manifest themselves in blurred and fluid visuals can be followed by the intellectual montage. While in the abstract map of the intellectual montage that manifests "the emotive and cognitive powers" the spectator intellectually travels, there is a circumstance in the route of the abstract map presented in the Visions in Meditation tetralogy that the spectator can be lost in its abstraction (Carrol, 2003, p.138). As Michelson (2005, p.42) emphasised, "For Brakhage, poetry undoubtedly plays the revelatory role that theater had for Eisenstein".

In the Visions in Meditation series inspired by different subjects, the camera, as a part of Brakhage's body that moves on its own, is activated to capture any moment "encountered in life through an adventure of perception" (Brakhage, 1963, p.30). The camera, which does not have to be taken under control, records the surroundings without the constraint of movement within and out of focus. Removing "the boundaries and distances" like the Kino-eye, Brakhage's camera eye blurs the boundaries and distances, thus the "objectivity" as defined by Deleuze (1983/1986, p.80-82) and detaches it from reality. As Wees mentioned, in contrast to the "mechanical" formation of Vertov's Kino-eye, Brakhage's eye is "participant-observer". In addition, the metaphor of the camera-eye, in Wees words, "is the basis of the dialectical relationship of eye and camera, from which the visual aesthetics of avant-garde film have emerged (Wees, 1992, p.14-24).”

Brakhage creates a relationship between the shots in an experimental way by using overlapping and blending images, cutting, fade out, fade in, jump cuts, and their possible combinations to convey his own perspective in an expressionist 
way. Deleuze (1983/1986, p.113) expresses that "the cinema is not simply the camera: it is montage" and "from the point of view of the human eye, montage is undoubtedly a construction" therefore, unlike Vertov who approaches the editing as form of reifying, Brakhage's images become abstract during their construction which leads them to detach from the perception of the reality.

\section{CONCLUSION}

Eisenstein, the leading theorist of editing, which is the basis of the research, aimed to create a more intense, influential and deeper impact on people with the montage methods and theories he presented. Eisenstein who puts the intellectual aspects of the cinema on the forefront and depicts the abstract concepts through the usage of intellectual editing resonates with the audience's intellectual process. Besides Eisenstein, Vertov opened up the usage of editing in an innovative way and tried to let audience see "which the eye doesn't see" through Kino-Eye. Editing, which is highly important for Russian avant-garde cinematography due to its structure of joining parts together as a combination and an organization, found its place within the art universe of Constructivism that was evolved on account of the conditions of the era. Russian avant-garde filmmakers transcended the limitations of their era by using their editing techniques developed for conveying the reality as best as they can.

This research that tackles editing's abstract narrative in Stan Brakhage's Visions in Meditation tetralogy found that even though the muse of the work comes from social subjects, the visual language of the subject can be classified as intellectual editing which focuses on the abstract. The research also found out that the visual narrative of the tetralogy becomes isolated and done with aesthetic concerns.

Within the context for the hypotheses;

1. For an artist who accepts the cinema as an art discipline, editing is not only a technical tool, but also an aesthetic concern.

2. Editing as an artistic concern can both create a sense of reality and detach the film from its reality.

The results of the samples examined within the scope of the research show that for Stan Brakhage, who uses cinema as an art discipline, the technical process in the editing is also a process where the artist builds his own aesthetic language. Just like an expressionist artist painting on a canvas, editing becomes the paintbrush of Stan Brakhage's expressionist technique and aesthetic language. 
Abstraction Through Editing in Experimental Cinema: Visions in Meditation...

What actually becomes incepted in Visions in Meditation is Brakhage's aesthetic language. Visions in Meditation tetralogy, which is not a solely abstract work, utilizes its own foundations in reality through different locations, times and dialogues and then in turn abstracts them with the usage of editing. Stan Brakhage creates his own aesthetic language while reflecting his perspective through cinema. Editing in this sense utilized as both a tool and a point of perception within the movie.

\section{KAYNAKÇA / REFERENCES}

Baker, U. (2011). Beyin Ekran. Birikim Yayınları.

Bazin, A. (2005) What Is Cinema?: Volume I (H. Gray, transl.) (p.23-40). University of California Press (Release date of original work 1967). http://www.jstor.org/stable/10.1525/j.ctt5hjhmc.8 Accessed: 28.02.2021

Bazin, A. (2005) What Is Cinema?: Volume II (H. Gray, transl.) (p.61-78) University of California Press (Release date of original work 1967). http://www.jstor.org/stable/10.1525/j.ctt5hjhjd.9 Accessed: 28.02.2021

Bordwell, D., \& Thompson, K. (1997). Film Art: An Introduction (5 ${ }^{\text {th }}$ Edition) McGrow-Hill.

Bordwell, D., \& Thompson, K. (2011). Film Sanatı (E. Y1lmaz ve E. S. Onat, Çev.). Deki Yayınları (Release date of original work 1979).

Brakhage, M. (2008). On Stan Brakhage and Visual Music. Vantage Point. https://vantagepointmagazine.wordpress.com/2008/01/31/on-stanbrakhage-and-visual-music/ Accessed: 28.02.2021

Brakhage, M. (2010) Some Notes on the Selection of Titles By Brakhage: An Anthology, Volume Two. Criteion. https://www.criterion.com/current/posts/1471-some-notes-on-theselection-of-titles-for-by-brakhage-an-anthology-volume-two Accessed: 28.02.2021

Brakhage, S. (1963) Metaphors on Vision. Film Culture. https://archive.org/details/metaphorsonvisio00brak/page/n29/mode/2up?v iew=theater Accessed: 28.02.2021

Brakhage, S. (Director). (1989). Visions in Meditation \#1 [Film] United States of America.

Brakhage, S. (Director). (1989). Visions in Meditation \#2 Mesa Verde [Film] United States of America. 
Brakhage, S. (Director). (1990). Visions in Meditation \#3 Plato's Cave [Film] United States of America.

Brakhage, S. (Director). (1990). Visions in Meditation \#4 D. H. Lawrence [Film] United States of America.

Carrol, N. (2003). Eisenstein's Philosophy of Film. Allen, R. ve Malcolm, T. (Ed.), Camera obscura, camera lucida: Essays in Honor of Annette Michelson (p.136-141). Amsterdam University Press.

Deleuze, G. (1986). Cinema 1 The Movement-Image. (H. Tomlinson and B Habberjam, transl.). The Athlone Press (Release date of the original work 1983).

Eisenstein, S. (1977). Film Form. (J. Leyda, Transl.) Harcourt, Brave World Inc. (Release date of the original work 1949).

Göztepe, M. O. (2010) Politik Sinema Olanağ Olarak Deneysel Sinema Unpublished master's thesis, (p.67). Marmara University Institute of Social Sciences.

Holl, U. (2017). Cinema, Trance and Cybernetics. Amsterdam University Press.

Kracauer, S. (1960). Theory of Film, The Redemption of Physical Reality. Oxford University Press.

Michelson A. (2005). Camera Lucida / Camera Obscura. James, D., E, (Ed), Stan Brakhage Filmmaker (p.36-56). Temple University Press.

Özön, N. (2014). Giriş: Eisenstein - Yaşamı, Yapıtı, Kuramı. S. Eisenstein Film Dиуити (p. xvii-clxxxviii). Agora Kitaplığı

Sitney, A., P. (2003) Stan Brakhage. https://www.fredcamper.com/Brakhage/Sitney.html Accessed: 28.02.2021

Sitney , A., P. (2008). Eyes Upside Down: Visionary Filmmakers and the Heritage of Emerson . Oxford University Press.

Sitney, A., P. (2015) The Cinema of Poetry. Oxford University Press.

Tekinsoy, R. (2005). Rekin Teksoy'un Sinema Tarihi. Oğlak Yayıncılık

Vertov, D., ve Michelson, A., (1984). Kino-eye: The writings of Dziga Vertov (O’Brien, K. transl.). University of California Press. 
Abstraction Through Editing in Experimental Cinema: Visions in Meditation...

Wees, William C. (1992). Light Moving in Time: Studies in the Visual Aesthetics of Avant-Garde Film (S.11-24). University of California Press http://ark.cdlib.org/ark:/13030/ft438nb2fr/ Accessed: 28.02.2021

Wollen, P. (1972). Signs and Meaning in the Cinema (3rd Edition). Indiana University Press.

\section{WEBSITE REFERENCES}

https://www.tate.org.uk/art/art-terms/a/avant-garde Erişim tarihi: 28.02.2021

https://canyoncinema.com/catalog/film/?i=494 Erişim tarihi: 28.02.2021

https://canyoncinema.com/catalog/film/?i=495 Erişim tarihi: 28.02.2021

https://canyoncinema.com/catalog/film/?i=496 Erişim tarihi: 28.02.2021

\section{EXTENDED ABSTRACT}

Purpose: Editing that can direct the course of cinematic narrative was especially developed differently by Russian avant-garde cinematographers. Russian avantgarde cinematographers used the editing to a great extent in order to transmit the reality as it is in their films. Editing is an important aspect of the artist's aesthetic language as well as a technical tool. While editing can be used to utilize the reality as it is, it can also be used to isolate the films from their realities. Especially in experimental cinematography, editing became a tool that can create the perception of the intangible. This paper examines the usage of editing in experimental cinematography as an artistic tool as well as a tool that can detach the film from its reality.

Methodology: The research limits itself to the experimental fictional film category while maintaining its focus on Stan Brakhage's Visions in Meditation short movie tetralogy and its editing practices. Stan Brakhage's importance among the avant-garde cinematographers and his contributions to the concept and aesthetics of the films in general are the main reasons behind the selection of Brakhage. The hypotheses presented through the research are as follows:

1. For an artist who accepts the cinema as an art discipline, editing is not only a technical tool, but also an aesthetic concern.

2. Editing as an artistic concern can both create a sense of reality and detach the film from its reality. 


\section{Serkan ÖZTÜRK \& Ecem GÜLEÇ}

These hypotheses are built upon the ideas of montage methodology of Eisenstein which puts an emphasis on the power of editing in cinema theory, the concept of Avant-garde cinema which is a commonality that both Eisenstein and Brakhage bears, and within the concept of experimental cinema, Vertov's Kino-Eye theory which creates the idea of perceptional editing. These ideas are used in this research to examine the Brakhage's Visions in Meditation tetralogy to identify its editing, cinema theories and effect on the eye of the beholder. At the conclusion, the findings and approaches are also discussed.

Findings: Brakhage in his Visions in Meditation that are inspired by different subjects, uses overlapping images, cutting, fade out, fade in, jump cuts, quick cuts, and their possible combinations to convey his own perspective in an expressionist way. For Deleuze "... the cinema is not simply the camera: it is montage" (1983/2014, p.113) and "...from the point of view of the human eye, montage is undoubtedly a construction..." therefore, unlike Vertov who approaches the editing as form of reifying, Brakhage's image building in his movies become abstract and detaches it from the perception of the reality.

While Visions in Meditation tetralogy which is constructed from shots of different times and different locations, continues the same path by combining conflicting imagery with intellectual editing, it differentiates from intellectual editing that reify the "abstract concepts" by abstracting the tangible concepts instead. Although in the abstract map of intellectual editing that incepts cognitive and emotive powers, audience are present intellectually in the moment; in the abstract map of Visions in Meditation tetralogy, audience can be intellectually lost in the moment. Built on an obscure and vague narrative, Visions in Meditation's imagery becomes abstract at moments which makes the correlation between fluid and blurry images intrinsically followable with intellectual editing. As Michelson (2005, p.42) describes it: "For Brakhage, poetry undoubtedly plays the revelatory role that theater for Eisenstein".

Conclusion: Eisenstein who puts the ideational aspects of the cinema on forefront and depicts the abstract concepts through the usage of intellectual editing resonates with the audience's intellectual process. In addition to Eisenstein, Vertov who opened the usage of editing in an innovative way and with Kino-Eye tried to let audience see "that which the eye doesn't see". Editing, which is highly important for Russian avant-garde cinematography, existed within the art universe of Constructivism that is produced by the era's condition. Russian avant-garde cinematographers by using their editing techniques that are 
Abstraction Through Editing in Experimental Cinema: Visions in Meditation...

developed for conveying the reality as best as they can transcended the limitations of their era.

This research that tackles fiction's abstract narrative in Stan Brakhage's Visions in Meditation tetralogy found that even though the muse of the work comes from social subjects, visual language of the subject can be classified as intellectual editing which focuses on the abstract. The research also found out that visual narrative of the tetralogy becomes abstracted and done with aesthetic concerns.

Within the context of the hypotheses;

1. For an artist that accepts the cinema as an art discipline, editing is not only a technical tool but also an aesthetic concern.

2. Editing as an artistic concern can both create a sense of reality and detach the film from its reality.

The results show that in the editing of Visions in Meditation by Stan Brakhage, who uses cinema as an art discipline, the technical process in the editing is also a process where the artist builds his own aesthetic language. Just like an expressionist artist painting on a canvas, editing becomes the paintbrush of Stan Brakhage's expressionist technique and aesthetic language.

What actually becomes incepted in Visions in Meditation is Brakhage's aesthetic language. Visions in Meditation tetralogy, which is not a solely abstract work, utilizes its own foundations in reality through different locations, times and dialogues and then in turn abstracts them with the usage of editing. Stan Brakhage creates his own aesthetic language while reflecting his perspective through cinema. Editing in this sense utilized as both a tool and a point of perception within the movie. 